\title{
MANAJEMEN KOLABORASI DALAM MENINGKATKAN MUTU PENDIDIKAN MASYARAKAT (STUDI DESKRIPTIF PADA ORGANISASI IKATAN KELUARGA BESAR BARINGIN SIP)
}

Saparripin Idris, Doharni Rambe, Devi Afriani, Heny Hastuti

\author{
Sekolah Tinggi Agama Isla m Sumatera Medan \\ Jl. Sambu No. 44/64, Kota Medan, Sumatera Utara \\ e-mail: saparripinsaid@gmail.com, harnyrambe@gmail.com, devii03031996@gmail.com, \\ henyhastutih@gmail.com
}

\begin{abstract}
Abstrak: Penelitian in bertujuan untuk menganalisis manajemen kolaborasi (perencanaan, pelaksanaan dan pengawasan) dalam meningkatkan mutu pendidikan yang dilakukan oleh organisasi Ikatan keluarga besar Baringin Sip (IKBSS). Metode yang digunakan ialah kualitatif dengan menggunakan pendekatan studi deskriptif. Pengumpulan data menggunakan observasi, wawancara, dan studi dokumentasi. Analisis data melalui tahapan reduksi data, verifikasi data, dan penarikan kesimpulan. Uji keabsahan data menggunakan trianggulasi dan member check. Adapun Hasil penelitian memaparkan bahwa majamen kolaborasi dilakukan oleh organisasi Ikatan keluarga Besar Baringin Sip (IKBSS) dengan lembaga pendidikan formal dan nonformal yang ada di desa Baringin tersebut. Manajemen kolaborasi tersebut berkaitan dengan perencanaan, pelaksanaan dan pengawasan. Dalam hal perencanaan IKBSS berkolaborasi dalam menyusun program dan menyusun anggaran pendidikan. Dalam hal pelaksanaan IKBSS mendukung secara langsung dengan turut terlibat untuk mendidik dan mengontrol jalannya program pendidikan. Dalam hal pengawasan dengan cara mengevaluasi ketercapaian program dan mengevaluasi realisasi penggunaan anggaran pendidikan.
\end{abstract}

Kata Kunci: Manajemen Kolaborasi, Mutu Pendidikan, Masyarakat

\begin{abstract}
This study aims to analyze the various forms of collaborative management (planning, implementation and monitoring) in improving the quality of education carried out by Ikatan keluarga besar Baringin Sip (IKBSS). The method used is qualitative by using a descriptive study approach. Collecting data using observation, interviews, and documentation studies. Data analysis through the stages of data reduction, data verification, and drawing conclusions. Test the validity of the data using triangulation and member check. The results of the research explain that collaboration management is carried out by Ikatan keluarga besar Baringin Sip (IKBSS) organization with formal and non-formal educational institutions in the Baringin village. The collaborative management relates to planning, implementation and monitoring. In terms of planning, IKBSS collaborates in preparing programs and preparing education budgets. In terms of implementation, IKBSS supports directly by being involved in educating and controlling the course of education programs. In terms of supervision by evaluating the achievement of the program and evaluating the realization of the use of the education budget.
\end{abstract}

Keywords: Collaboration Management, Quality of Education, Community 
Hikmah, Vol. 18, No. 1, Januari-Juni 2021, p-ISSN: 1829-8419 e-ISSN: 2720-9040

\section{PENDAHULUAN}

Pergeseran pendidikan dalam penyelenggaraan sistem pemerintahan di Indonesia telah berimbas pada pengelolaan sistem pendidikan, yakni semula yang lebih bersifat sentralistik bergeser kearah pengelolaan yang bersifat desentralistik. (H. Usman, 2016). Pendidikan ditunjukan untuk meningkatkan kualitas sumber daya manusia, sebagaimana dirumuskan dalam Undang-Undang Republik Indonesia nomor 20 tahun 2003 tentang Sistem Pendidikan Nasional bab II pasal 3 yakni pendidikan nasional berfungsi mengembangkan kemampuan dan membentuk watak serta peradaban bangsa yang bermartabat dalam rangka mencerdaskan kehidupan bangsa, bertujuan untuk mengembangkan potensi peserta didik agar menjadi manusia yang beriman dan bertaqwa kepada Tuhan Yang Maha Esa, berakhlak mulia, sehat berilmu, cakap, kreatif, mandiri, dan menjadi warga Negara demokratis serta bertanggung jawab.

Rendahnya kualitas sumber daya manusia merupakan masalah yang dapat menghambat pembangunan dan perkembangan pendidikan. Perkembangan pendidikan perlu diupayakan secara bertahap dan berkesinambungan baik dalam jalur pendidikan formal, mulai dari pendidikan dasar sampai pendidikan perguruan tinggi. (Leonard, 2016). Salah satu langkah reformasi internal di bidang pendidikan yang harus dilakukan segera adalah mengembalikan otonomi pedagagogis kepada sekolah dan guru. Selain itu, sekolah dan guru perlu diberi peranan lebih besar untuk ikut menyusuri program belajar dan agenda evaluasi. Ia yakin selama hal tersebut tidak dilakukan perubahan, maka selama itu pula sekolah dan guru tidak akan dapat melaksanakan tugasnya mendidik secara benar, selama itu pula kita tidak akan memperbaiki kesalahan-kesalahan fundamental yang terjadi di sekolah-sekolah. (Meirawan, 2015).

Kualitas yang baik dalam suatu lembaga pendidikan ditentukan oleh suatu perencanaan yang baik di dalam sebuah manajemen. Untuk menghasilkan output yang berkualitas dibutuhkan penerapan dan pengelolaan manajemen yang baik, untuk melaksanakan sesuatu dengan tertib, teratur dan terarah diperlukan adanya manajemen. (Gaol, 2020). Manajemen merupakan ilmu dan seni mengatur prosespemanfaatan sumber daya manusia dan sumber-sumber lainnya secara efektif dan efisien untuk mencapai suatu tujuan tertentu. Adanya formula baru dalam dunia pendidikan, dalam pengelolaan baru disekolah merupakan suatu upaya untuk meningkatkan mutu pendidikan efisiensi dan pemerataan. Formula baru ini memungkinkan sekolah memiliki otonomi yang luas, dan manajemen kebijakan nasional tidak terabaikan. Pengelolaan model baru inilah yang disebut Manajemen Berbasis Sekolah (School Based Management) yang biasa disingkat MBS. (Hamid, 2013). manajemen berbasis sekolah merupakan suatu konsep yang menawarkan otonomi pada sekolah dalam rangka peningkatan mutu, efisiensi dan pemerataan pendidikan agar dapat 
mengakomodasi keinginan masyarakat setempat serta menjalin kerjasama yang erat antara sekolah, masyarakat, dan pemerintah. (A. S. Usman, 2014).

Manajemen berbasis sekolah tentu akan berjalan dengan baik mana kala tercipta kolaborasi yang solid antar seluruh stakeholder pendidikan. Walaupun konsep manajemen ini menekankan pada aspek otonomi, namun bukan berarti ini melepaskan tanggung jawab kebersamaan. Sebagaimana juga diketahui bahwa pendidikan merupakan sistem, itu artinya terdapat beberapa komponen yang satu sama lain saling mempengaruhi untuk mencapai tujuan yang telah ditentukan. Oleh karena itu sangat lah sulit rasanya jika pendidikan tidak bekerjasama antar ragam komponen tersebut. (Sasongko, 2015).

Pendidikan bukan hanya menjadi tanggung jawab pemerintah semata, akan tetapi juga menjadi tanggung jawab masyarakat, baik dalam pengelolaanya maupun juga dalam segi finansial atau keuanganya. Tanggjung jawab tentu dilakukan dengan peran dan fungsi masing-masing, hal ini lah kemudian yang disebut dengan manajemen kolaborasi. Kerjasama ataupun kolaborasi tidak serta merta menentukan keberhasilan tujuan yang telah di cita-citakan, sebab kolaborasi dan kerjasama tentu membutuhkan pengaturan dan pengelolaan tersendiri, pengelolaan ini lah yang kemudian disebut dengan manajemen kolaborasi. (Mubarok, 2011).

Organisasi Ikatan Keluarga Besar Baringin Sip salah satu organisasi yang memiliki kepedulian terhadap mutu pendidikan, khususnya pendidikan di masyarakat Desa Baringin. Terdapat beberapa program yang memang dikhususkan untuk meningkatkan mutu pendidikan, namun tentu saja organisasi ini tidak berjalan sendiri, terdapat kerjasama yang dilakukan baik, kepada lembaga pendidikan, tokoh pendidikan, pemangku kebijakan pendidikan dan lainlain. Tentu dalam pelaksnaan kerjasama ini terdapat beberapa aturan pengelolaan. Sosialisasi dan musyawarah program sekolah merupakan jalan yang efektif agar peran masyarakat menjadi semakin nyata dalam pelibatan urusan sekolah. Hubungan inilah yang akan mendorong terciptanya hubungan yang harmonis antara kedua belah pihak. Maka penelitian ini bertujuan untuk menganalisis tata kelola atau manajemen kolaborasi dalam hal peningkatan mutu pendidikan di Desa Baringin.

Untuk mengetahui novelty penelitian ini, akan dikemukakan beberapa penelitian terdahulu yakni manajemen kolaborasi pada pemberdayaan anak (Munawir et al., 2018), prinsip majamen kolaborasi pada anak (Dahlan \& Darwis, 2017), Model Collaborative Management (Bénaben et al., 2013), dari beberapa penelitian tersebut tampak tidak menyentuh pada aspek pendidikan, manajemen kolaborasi yang akan dijelaskan ini berimpilkasi pada peningkatan mutu pendidikan di masyarakat Desa Baringin. 
Hikmah, Vol. 18, No. 1, Januari-Juni 2021, p-ISSN: 1829-8419 e-ISSN: 2720-9040

\section{METODE PENELITIAN}

Penelitian ini mengkaji dan mendeskripsikan tentang penerapan Manajemen Kolaborasi Dalam Memotivasi Majunya Pendidikan Masyarakat Baringin .Sesuai dengan fokus penelitian,maka penelitian ini menggunakan pendekatan kualitatif. Jenis penelitian yang digunakandalam penelitian ini adalah penelitian deskriptif. Penelitian deskriptif merupakan penelitian yang berusaha mendeskripsikan data yang ada. Disamping itu penelitian deskriptif terbatas pada usahamengungkapkan suatu masalah atau dalam keadaan ataupun peristiwa sebagaimanaadanya, sehingga bersifat sekedar mengungkapkan fakta.

Penelitian ini dilaksanakan di Organisasi ikatan keluaga besar baringin sip (IKBBS) yang berada di Kec Dolok, Kab Padang Lawas Utara, Sumatera utara. Penelitian ini dilaksanakan dari bulan Oktober 2020 sampai dengan April 2021. Waktu penelitian tersebut dimulai dari perencanaan penelitian, pelaksanaan penelitian, sampai pada penulisan laporan penelitian.

Sumber data penelitian terdiri dua yakni sumber Data Primer dan sumber data sekunder. Sumber data primer pada penelitian ini ialah data yang diperoleh secara langsung dari sumber pertamayang dilakukan melalui wawancara, observasi dan alat lainnya. Data primer yangdiperoleh peneliti berasal dari hasil wawancara dengan ketua organisasi dan beberapa anggota di organisasi tersebut. Sedangkan sumber data sekunder pada penelitian ini ialah data yang sudah tersedia dalam bentuk dokumen ataupun dari bahan kepustakaan dan dapat diperoleh peneliti dengan membaca, melihat ataupun mendengarkan.

Pengumpulan data ini menggunakan beberapa cara yang dianggap relevan dengan penelitian, yaitu sebagai berikut observasi, wawancara, dokumentasi. Sedangkan analisis data menggunakan teknik induktif yaitu dengan cara menganalisa data yang bersifat khusus (fakta empiris) kemudian mengambil kesimpulan secara umum (tataran konsep). Secara tahapan analisis data terdiri dari reduksi data, penyaian data, dan penarikan kesimpulan. Kemudian untuk keabsahan data dilakukan dengan perpanjangan pengamatan, meningkatkan ketekunan, triangulasi, menggunakan bahan referansi lain, dan member check.

\section{HASIL DAN PEMBAHASAN}

Sebagaimana yang telah dikemukakan sebelumnya bahwa penelitian ini untuk menganalisis pola manajemen kolaborasi yang dilakukan oleh Organisasi Ikatan Keluarga Besar Baringin Sip dengan lembaga pendidikan, masyarakat (komite pendidikan). Berikut ini akan dikemukakan manajemen kolaborasi tersebut mulai dari dari perencanaan, pelaksanaan dan suvervisi.

\section{Perencanaan Pendidikan}

Perencanaan pendidikan dilakukan terhadap jalur pendidikan formal dan juga pendidikan nonformal. Pendidikan formal, lazimnya pada tiap memasuki ajaran baru menyusun ragam perencanaan kegiatan 
Hikmah, Vol. 18, No. 1, Januari-Juni, p-ISSN: 1829-8419 e-ISSN: 2720-9040

peningkatan mutu pendidikan, dan lazimnya juga di ikuti masyarakat dan perwakilan dari organisasi dan tokoh masyarakat setempat. Hasil wawancara dengan ketua Organisasi Ikatan Keluarga Besar Baringin Sip (IKBBS) keterlibatan ragam unsur masyarakat ini bertujuan sebagaimana berikut ini:

- Mengidentifikasi kebutuhan pendidikan dari masyarkat sehingga pelaksanaan pendidikan sesuai dengan harapan dan cita-cita pendidikan

- Mengidentifikasi permasalahan pendidikan yang sedang di hadapi, sehingga dapat perencanaan tersebut dapat menjadi solusi terhadap permasalahan yang sedang dihadapi

- Sumbangsih saran dan masukan terkait dengan program pendidikan yang akan dilaksanakan

- Menggali ragam potensi yang ada pada ragam unsur tersebut sehingga dapat dimanfaatkan pada program pendidikan yang ada

- Menyusun anggaran dan program pendidikan yang akan dilaksanakan pada tahuan ajaran baru

- Mengevaluasi pelaksanaan program pendidikan yang telah terlaksana pada sebelumsebelumnya
Perencanaan

pendidikan menyangkut dua hal, yakni perencanaan anggaran dan perencanaan program. Perencanaan anggaran pendidikan pada dasarnya dilakukan terhadap sekolahsekolah yang dikelola oleh masyarakat, akan tetapi tidak juga menutup kemungkinan juga dilakukan pada sekolah berbasis pemerintah. Perwakilan masyarakat di lembaga pendidikan terkumpul dalam satu wadah yang disebut dengan komite sekolah. komite sekolah adalah agar suatu organisasi masyarakat sekolah yang mempunyai komitmen dan loyalitas serta peduli terhadap peningkatan kualitas sekolah. Komite sekolah yang dibentuk dapat dikembangkan secara khas dan berakar dari budaya, demografis, ekologi, nilai kesepakatan, serta kepercayaan yang dibangun sesuai dengan potensi masyarakat setempat. Oleh karena itu, komite sekolah yang dibangun harus merupakan pengembangan kekayaan filosofis masyarakat secara kolektif. Artinya, komite sekolah mengembangkan konsep yang berorientasi kepada pengguna (client model), berbagai kewenangan (power sharing and advocacy model), dan kemitraan (partnership model) yang difokuskan pada peningkatan mutu pelayanan pendidikan. (Utari, 2015).

Dalam hal perencanaan program pendidikan komite sekolah bertugas memberikan pertimbangan dalam penentuan dan pelaksanaan kebijakan pendidikan; menggalang dana dan sumber daya pendidikan lainnya dari masyarakat baik perorangan usaha/dunia industri maupun pemangku kepentingan lainnya 
Hikmah, Vol. 18, No. 1, Januari-Juni 2021, p-ISSN: 1829-8419 e-ISSN: 2720-9040

melalui upaya kreatif dan inovatif. Dari tugas ini tampak bahwa masyarakat dalam hal ini yang terwakili oleh Organisasi Ikatan Keluarga Besar Baringin Sip (IKBBS) memiliki peranan yang penting dalam hal peningkatan mutu pendidikan di desa tersebut. (Septiana et al., 2018).

Beberapa progam yang diusulkan terkait dengan peningkatan mutu pendidikan sebagai berikut:

- Fokus pembelajaran yang tidak hanya pada sisi kognitif tapi juga mengarah pada orientasi afektif dan spiritual. Program ini ditawarkan mengingat banyaknya permasalahan moral yang terjadi di tengah-tengah masyarakat

- Penambahan ekstrakurikuler yang dapat meningkatkan minat dan bakat anak, terutama yang berkaitan dengan tuntutan perkembangan para siswa

- Pembelajaran yang memfasilitasi siswa untuk mampu menghadapi tantangan era revolusi industri 4.0

- Program pembelajaran berbasis kearifan lokal. Dalam hal ini difokuskan untuk mengarahkan siswa agar memahami kebudayaan derah tempat tinggal mereka, dan mampu untuk melestarikan kebudayaan tersebut.

- Program pembelajaran inklusif, yang memberikan akses bagi siswa dengan keterbatasan. Hal ini memungkinkan untuk siswa-siswa dengan keterbatasan fisik atau psikis, sebab daerah terkadang tidak memiliki lembaga pendidikan yang memang mengkhususkan diri pada siswa-siswa keterbatasan tersebut.

Terkait dengan pembiayaan peran komite terhadap sekolah antara lain dalam bantuan-bantuan berupa pembiayaan sekolah dan bantuan berupa masukan dan pendapat dalam pengembangan sekolah (gedung, sarana, prasarana) lewat BP3 yang pada saat ini adalah komite sekolah atau secara langsung perorangan atau kelompok. Kemudian penyediaan tempat untuk mendirian sekolah atau lapangan sekolahdan lain-lain untuk keperluan sekolah. Dukungan dari komite sekolah dalam pengadaan saran dan prasarana sekolah sangat besar. Dengan adanya dana yang disumbangkan dari orang tua siswa maka kebutuhan sarana dan prasarana sekolah bisa terpenuhi walaupun belum sepenuhnya. Kemudian dengan adanya bantuan masyarakat dalam pengelolaan sarana dan prasarana sekolah maka kami pihak komite turut memfasilitasi dengan apa yang dibutuhkan oleh sekolah.

\section{Pelaksanaan Pendidikan}

Dalam hal manajemen kolaborasi, khusus dalam pelaksanaan pendidikan Organisasi Ikatan Keluarga Besar Baringin Sip (IKBBS) memberikan dukungan terhadap semua kegiatan yang telah disetujui untuk dilaksanakan. Dukungan dapat berupa lansung ataupun tidak langsung. Dukungan Langsung berupa terlibat langsung dalam kegiatan pendidikan yang telah ditetapkan untuk dilaksanakan. Dalam hal ini seperti misalnya menjadi tenaga pengajar, atau 
Hikmah, Vol. 18, No. 1, Januari-Juni, p-ISSN: 1829-8419 e-ISSN: 2720-9040

terlibat mengurusi hal-hal yang berkaitan dengan program pendidikan. Dalam hal tidak langsung berupa tindakan moril seperti membantu kelancaran semua program, dan tidak menentang program yang telah direncanakan sejak awal kegiatan.

Secara rinci dukungan langsung dapat dilihat pada rincian di bawah ini:

- Terlibat sebagai tenaga pendidik atau tenaga kependidikan di lembaga pendidikan yang menjadi kolaborasi atau kerjasama dalam program peningkatan mutu pendidikan

- Ikut serta menuntun jalannya program pendidikan, sehingga dipastikan program tersebut berjalan sesuai yang telah direnacanakan.

- Terlibat dalam laju perkembangan program, bahkan berhak untuk mengusulkan pemberhentian program jika tidak sesuai dengan yang direncanakan.

- Terlibat memanage semua kegiatan program, termasuk dalam memeriksa laporan kegiatan program yang nantinya telah dilaksanakan.

Peningkatan mutu layanan pendidikan membutuhkan program dankegiatan serta dukungan dana dan sarana prasarana pendidikan agar mampu memenuhi harapan peserta didik dan masyarakat. Oleh karena itu sarana dan prasarana memegang peranan yang sangat strategis dalam proses pendidikan. Terpenuhinya sarana dan prasarana pendidikan akan mampu meningkatkan pelaksanaan proses pendidikan, meningkatkan mutu pendidikan itu sendiri yang pada akhirnya akan meningkatkan kepuasan pelanggan sebagai pengguna jasa pendidikan. Oleh karena itu komite sekolah harus berperan dalam memfasilitasi kebutuhan sarana dan prasarana pendidikan di sekolah dengan memberdayakan sumber daya yang ada di masyarakat. (Munawir et al., 2018).

Pemenuhan sarana dan prasarana sesuai dengan kebutuhan sekolah untuk mencapai tujuan sekolah yang telah ditetapkan merupakan upaya komite sekolah dalam meningkatkan mutu layanan pendidikan melalui peran dan fungsi komite sekolah untuk mendukung keterlaksanaan proses pendidikan. Sarana dan prasarana pendidikan seperti gedung sekolah, alat dan media pembelajaran, sumber daya manusia dan lain sebagainya yang digunakan dalam kegiatan belajar mengajar harus terpenuhi dengan baik. Pendidikan adalah upaya sadar untuk memfasilitasi perkembangan dan peningkatan potensi peserta didik. Inti dari pendidikan adalah kegiatan pembelajaran. Untuk itu perlu adanya program dan dukungan untuk melaksanakannya. Kegiatan penggalangan dana untuk pendidikan yang dilakukan oleh komite sekolah sangat memperhatikan kondisi sosial ekonomi orang tua peserta didik, hal ini terlihat dengan dilaksanakannya konsep subsidi silang dalam penarikan iuran dana pendidikan oleh komite sekolah. Hal ini 
Hikmah, Vol. 18, No. 1, Januari-Juni 2021, p-ISSN: 1829-8419 e-ISSN: 2720-9040

dimaksudkan agar siswa yang berasal dari keluarga kurang mampu tetap dapat bersekolah dengan bantuan dari siswa dari keluarga yang lebih mampu.

Dalam melaksanakan perannya untuk meningkatkan mutu layanan pendidikan adalah sebagai berikut:

- Memberikan pertimbangan dalam hal pendataan kondisi sosial ekonomi keluarga peserta didik dan sumber daya pendidikan yang ada dalam masyarakat. Memberikan masukan dan pertimbangan kepada sekolah dalam penyusunan visi, misi, tujuan, kebijakan dan kegiatansekolah.

- Memberikan pertimbangan kepada sekolah dalam rangka pengembangan kurikulum muatan lokal, dan meningkatkan proses pembelajaran dan pengajaran. Memverifikasi RAPBS yang diajukan oleh kepala sekolah, memberikan pengesahan terhadap RAPBS setelah proses verifikasi dalam rapat pleno komite sekolah.

- Memberikan dukungan kepada sekolah untuk secara preventif memberantas penyebarluasan narkoba di sekolah, memberikan dukungan kepada sekolah dalam Pelaksanaan kegiatan ekstrakurikuler. Melaksanakan konsep subsidi silang dalam penarikan iuran dari orang tua siswa.

- Melakukan pengawasan terhadap perencanaan dan pelaksanaan program dengan meminta penjabaran kepada sekolah tentang hasil belajar siswa, memberoleh masukan, saran, dan ide kreatif dari masyarakat.

- Membantu sekolah dalam menciptakan hubungan dan kerja sama antara sekolah dengan orang tua dan masyarakat. Mengadakan rapat atau pertemuan secara rutin atau insidental dengan kepala sekolah dan dewan guru. Meningkatkan kesadaran dan kemitraan masyarakat

\section{Pengawasan Pendidikan}

Pengawasan adalah suatu cara untuk menetapkan standar prestasi kerja dengan tujuan merencanakan sistem umpan balik informasi, membandingkan prestasi sesungguhnya dengan standar yang telah ditetapkan, menentukan adanya penyimpangan dan mengukur signifikansi penyimpangan tersebut, dan mengambil tindakan perbaikan yang diperlukan untuk menjamin bahwa semua. (Iskandar, 2016).

Pengawasan terhadap seluruh program yang ada juga dilakukan oleh Organisasi Ikatan Keluarga Besar Baringin Sip (IKBBS) baik secara langsung dan tidak langsung. Selain dalam bentuk pengawasan peran masyarakat dalam hal ini Organisasi Ikatan Keluarga Besar Baringin Sip (IKBBS) yang berafiliasi dalam komite sekolah juga bertugas sebagai pengontrol perwujudannya adalah dalam bentuk pengawasan terhadap proses pengambilan keputusan disekolah, melakukan penilaian terhadap kualitas kebijakan yang diambil sekolah, 
melakukan pengawasan terhadap proses dan kualitas perencanaan dan program sekolah, melakukan pengawasan terhadap organisasi sekolah,melakukan pengawasan terhadap alokasi anggaran untuk pelaksanaan program sekolah dan melakukan pengawasan terhadap partisipasi sekolah pada program sekolah.

Selain itu komite sekolah juga berperan serta dalam rangka transparansi penggunaan alokasi dana pendidikan termasuk dalam mengawasi penggunaan dana bantuan dari pusat yang mengalir ke sekolah agar lebih dapat dipertanggungjawabkan. Penggunaan dana baik yang berasal dari masyarakat maupun pemerintah dapat benar-benar efektif dan termonitor alokasinya, apakah sesuai dengan Rancangan Anggaran Pendapatan dan Belanja Sekolah (RAPBS) yang diajukan satuan pendidikan/sekolah. (Mukodi, 2019).

Seperti yang telah disebutkan sebelumnya bahwa keterlibatan Organisasi Ikatan Keluarga Besar Baringin Sip (IKBBS) terlihat dari dua bentuk yakni langsung dan tidak langsung. Keterlibatan langsung itu sperti yang tertera di bawah ini:

- Pengawasan terhadap perkembagan program atau hasil dari kegiatan program

- Pengawasan terhadap penggunaan anggaran pembiayaan terhadap program yang telah direncakanan

- Pengawasan terhadap laporan penggunaan anggaran pembiayaan. Komite sekolah dalam hal ini organisasi Ikatan Keluarga Besar
Baringin Sip (IKBBS), berhak untuk mendapatkan laporan keuangan dan berhak untuk mengevaluasi laporan keuangan tersebut.

- Pengawasan terhadap alokasi anggaran, dan memantau output sekolah dengan melakukan pengawasan hasil ujian akhir, memantau hasil prestasi yang didapat dari bidang akademik maupun nonakademik, sedangkan untuk memantau alumni pihak komite tidak berdiri sendiri, tetapi dibantu oleh pihak alumni tingkat dan pihak sekolah yang berupa bentuk lisan dan tertulis. Untuk bentuk tertulis melalui pendataan dari sekolah

Komite sekolah dalam hubungannya dengan peran sebagai badan pengawas terhadap perencanaan pendidikan yakni dengan melakukan kontrol terhadap proses pengambilan keputusan di lingkungan dinas pendidikan termasuk penilian terhadap kebijakan yang ada. Adapun fungsi komite sekolah dalam melakukan pengawasan di suatu lingkup pendidikan adalah mengawasi pelaksanaan program di sekolah, alokasi dana dan sumber-sumber daya bagi pelaksanaan program tersebut. Di samping itu, penilaian terhadap hasil keluaran pendidikan di lembaga sekolah yang dilakukan oleh komite sekolah akan menjadi masukan bagi Dewan Pendidikan untuk memetakan persoalan dalam pemerataan dan mutu keluaran pendidikan 
Hikmah, Vol. 18, No. 1, Januari-Juni 2021, p-ISSN: 1829-8419 e-ISSN: 2720-9040

Pengawasan yang dilakukan oleh Organisasi Ikatan Keluarga Besar Baringin Sip (IKBBS) terjadwal sebanyak 2 kali dalam setahun, atau dikenal dengan pengawasan semester. Waktu ini ditetapkan karena memang secara terprogram perencanaan dilakukan setiap tahun, namun setiap semester akan dilaporkan perkembangan program, termasuk juga dalam hal laporan keuangan. Laporan semester ini kemudian akan menjadi landasan untuk revisi program atau revisi keuangan, jika ditemukan beberapa hal yan tidak sesuai dengan program-program yang ada. (Lestari, 2017).

\section{SIMPULAN}

Dari penjelasan hasil dan pembahasan penelitian di atas maka dapat disimpulkan beberapa hal yakni manajemen kolaborasi maksudnya adalah tata pengaturan yang berkaitan dengan kerjasama antara Organisasi Ikatan Keluarga Besar Baringin Sip (IKBBS) dengan lembaga pendidikan yang ada di desa Baringin. Tata pengaturan kolaborasi tersebut tampak melalui tiga kegiatan yakni perencanaan, pelaksanaan, dan pengawasan atau pengontrolan. Dalam hal perencanaan berkaitan dengan penyusunan ragam program kegiatan pendidikan, identifikasi kebutuhan dan permasalahan yang ada, penyusunan anggaran pembiayaan, menjalin keterlibatan pekerjaan masing-masing pihak. Dalam hal pelaksanaan, Organisasi Ikatan Keluarga Besar Baringin Sip (IKBBS) berperan mendukung seluruh program pendidikan yang telah disepakati baik formal ataupun non formal. Dukungan tersebut diberikan dalam bentuk langsung maupun tidak langsung. Dari segi langsung berupa keterlibatan secara aktif organisasi dalam pelaksanaan pendidikan bahkan tidak menutup kemungkinan juga menjadi pelaksana dari pendidikan itu sendiri. Sedangkan tidak langsung berkaitan dengan dukungan moril dan dukungan untuk mempromosikan dan mensosialisasikan semua program yang telah ada. Dalam hal pengawasan ataupun pengontrolan, dilakukan dengan dua acara yakni pengawasan terhadap program dan pengawasan terhadap anggaran.

\section{DAFTAR PUSTAKA}

Bénaben, F., Hanachi, C., Lauras, M., Couget, P., \& Chapurlat, V. (2013). A Meta Model and its Ontology to Guide Crisis Characterization and Its Collaborative Management. Proceedings of the 5th International Conference on Information Systems for Crisis Response and Management (ISCRAM), Washington, DC, USA, May, 4-7. https://d1wqtxts1xzle7.

Dahlan, D., \& Darwis, M. (2017). Prinsip Manajemen Kolaborasi Pembinaan Anak Jalanan di Kota Makassar. Jurnal Ad'ministrare, 4(1), 41-58. https://doi.org/10.26858/ja.v4i1.3445

Gaol, N. T. L. (2020). Sejarah dan konsep manajemen pendidikan. Jurnal Dinamika Pendidikan, 13(1), 79-88. https://doi.org/10.51212/jdp.v13i1.13 73

Hamid, H. (2013). Manajemen Berbasis Sekolah. Al-Khwarizmi: Jurnal Pendidikan Matematika dan Ilmu Pengetahuan Alam, 1(1), 87-96. 
https://doi.org/10.24256/jpmipa.v1i1. 86

Iskandar, D. (2016). Peran pengawas Pendidikan dalam Peningkatan Mutu Pendidikan SMP di Kabupaten Bima, Nusa Tenggara Barat. Jurnal Penelitian Ilmu Pendidikan, 9(2), 179-195.

https://doi.org/10.21831/jpipfip.v9i2. 12918

Leonard, L. (2016). Kompetensi Tenaga pendidik di Indonesia: Analisis Dampak Rendahnya kualitas SDM Guru dan Solusi Perbaikannya. Formatif: Jurnal Ilmiah Pendidikan MIPA, 5(3), 43-48. http://dx.doi.org/10.30998/formatif.v $5 \mathrm{i} 3.643$

Lestari, S. (2017). Implementasi peran Komite Madrasah Sebagai Pemberi Pertimbangan (Advisory Agency) di Madrasah Tsanawiyah Negeri Lipat Kain Kabupaten Kampar. Universitas Islam Negeri Sultan Syarif Kasim Riau. http://repository.uinsuska.ac.id/10341/

Meirawan, D. (2015). Penjaminan Mutu Satuan Pendidikan Sebagai Upaya Pengendalian Mutu Pendidikan Secara Nasional dalam Otonomi Pendidikan. Jurnal Educationist, 4(2), 126-137. http://file.upi.edu/Direktori/Jurnal/Ed ucationist/Vol._IV_No._2Juli_2010/08_Danny_Meirawan.pdf

Mubarok, A. (2011). Efektivitas Kolaborasi Manajemen Pembelajaran Madrasah Diniyah Takmiliyah Wustho dan Pendidikan Agama Islam dalam Membentuk Perilaku Agama Siswa di SMP Negeri 1 Anjatan Kabupaten Indramayu. IAIN Syekh Nurjati Cirebon. http://repository.syekhnurjati.ac.id/24 $73 /$.

Mukodi, M. (2019). Peranan Dewan
Pendidikan dalam Pengembangan Pendidikan di Kabupaten Pacitan di Era Revolusi Industri 4.0. Jurnal Penelitian Pendidikan, 11(1), 16081614.

https://www.ejournal.stkippacitan.ac.i d/index.php/jpp/article/view/290

MUNAWIR, I., Nengyanti, N., \& Mardianto, M. (2018). Manajemen kolaborasi Pusat Pelayanan Terpadu Pemberdayaan Perempuan dan Anak Kota Palembang. Sriwijaya University.

https://repository.unsri.ac.id/11968/

Sasongko, R. N. (2015). Strategi Mengatasi Madrasah Miskin Melalui Pengembangan Model Manajemen Berbasis Kolaborasi (Penelitian Tindakan Kependidikan di Berbagai Jenjang Madrasah di Provinsi Bengkulu). Madania: Jurnal Kajian Keislaman, 19(2), 120-134. http://dx.doi.org/10.29300/madania.v $19 \mathrm{i} 2.34$

Septiana, D. N., Bafadal, I., \& Kusumaningrum, D. E. (2018). Pelibatan Komite Sekolah dalam Peningkatan Mutu Pendidikan. JAMP: Jurnal Administrasi Dan Manajemen Pendidikan, 1(3), 293301.

http://dx.doi.org/10.17977/um027v1i 32018 p293

Usman, A. S. (2014). Meningkatan Mutu Pendidikan Melalui Penerapan Manajemen Berbasis Sekolah. Jurnal Ilmiah Didaktika: Media Ilmiah Pendidikan Dan Pengajaran, 15(1), 13-31.

http://dx.doi.org/10.22373/jid.v15i1.5 54

Usman, H. (2016). Peran Baru Administrasi Pendidikan: Dari Sistem Sentralistik Menuju Sistem Desentralistik. Jurnal Ilmu Pendidikan, $\quad 8(1), \quad$ 15-19. 
Hikmah, Vol. 18, No. 1, Januari-Juni 2021, p-ISSN: 1829-8419 e-ISSN: 2720-9040 http://dx.doi.org/10.17977/jip.v8i1.51 2

Utari, R. (2015). Kolaborasi SekolahOrangtua; Upaya Meningkatkan Keberfungsian Sosial Orangtua. Jurnal Manajemen Pendidikan UNY, 1(2), 114258. https://journal.uny.ac.id/index.php/jm p/index 